\title{
Marketing Accountability of Korea Corporate: The Relationship between Branding Investments and Financial Performance
}

\author{
Renee B. Kim, Dong Hyun Yoon
}

Hanyang University

608, School of Business, 222 Wangsimni-ro, Seongdong-gu, Seoul, Korea

E-mail.kimrby@gmail.com,midane2000@gmail.com

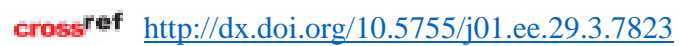

\begin{abstract}
Korea corporate recently made a major inroad to global brand ranking, and raised their firm values with considerable growth in brand equity. Carefully designed marketing investments may contribute to substantial growth of Korean firm's brand value and competitive strength in the global market. Brand equity is one of the most valuable assets of a firm and is considered to be a growth engine with the potential of lasting effects on the firm's performance and value. This study assesses the relationship between the firms' branding investments and their financial performance for the validation of marketing accountability. The authors examine Korean firm's brand equity from seventeen industries, using Simon and Sullivan's framework with the firm-level financial performance metrics based on firms' accounting and financial data. A sample 514 firms on the Korean Stock Exchange listing (i.e. KOSPI and KOSDAQ) from 17 different industries for the period of global financial crisis (2005-2010) are selected to evaluate comparable brand equity among the selected industries. Findings reveal that Korea Corporate's investments in marketing activities have a positive impact on brand equity and their financial performance. The study confirms the benefits of branding investments in Korea Corporate's financial performance.
\end{abstract}

Keywords: Business Economics (M2); Marketing \& Advertising (M3); Finance (G1).

\section{Introduction}

Firms increasingly emphasize the importance of brand equity in response to rapidly changing market platforms and consumer behavior. In globalized economies where product offers abound and choices for consumers seem endless, brands have become important management devices for differentiation and cognitive anchors for consumer-decision making (Muhlbacher et al., 2016). Brand equity is acknowledged as a key marketing performance indicator, a source of competitive advantage, and a vital component of business success (Christodoulides et al., 2015). A strategically managed brand name can serve as both a mean of differentiation in a crowded marketplace and as a method to convey unique brand associations and an image of quality (Heiens et al., 2012). Given the risk reduction inherent in the brand promise and the differentiating power of the brand, brands create value for both consumers and brand owners (Gray, 2006). Strong brands can dramatically enhance revenue capabilities of a product and raise the financial value of a firm, which may reflect brand equity. Brand equity is one of the most valuable assets of a firm and is considered to be a growth engine as it may have the potential of lasting effects on the firm's performance and value.

In the recent years Korea corporate made a major inroad to global brand ranking, and raised their firm values with considerable growth in brand equity. Korea's top fifty brand names present 125billion USD in 2017 with an annual growth rate of 6 percent (Kim, 2017). The total brand value of the 50 top Korea brands is approximately 14.3 percent of their total revenue, showing a continuous increase (Kim,
2017). Korea corporate brand power is considered to be the fifth in the world, following the US, Germany, Japan and France. Interestingly, Korean firms exhibited resilience in the downturn of the global economy (i.e. during the financial crisis) and continued to show positive growth. This may be due to their carefully designed marketing investments (i.e. advertising and promotion or buyout firms with wellestablished brands) which led to the creation of durable brand equity. Brands with a high degree of brand equity have strong influence on the profitability of a firm as strong brands deliver greater returns to stockholders and that they do so with less risk than strategies dependent on physical assets (Heines et al., 2012). Thus, brand equity provides sustainable competitive advantages as it creates meaningful competitive barriers (Chattopadhyay et al., 2008).

Korea's brands are well received in Asian market, while it is relatively weak in European and North American markets, which may require additional branding investments (Kim, 2017). To justify further branding investment for nonAsian market recognition, it may be worthwhile to assess the relationship between firms' marketing expenditure and their financial performance. Marketing accountability can be approximated by quantifying the return on marketing or branding investment of corporate. Although the corporate world recognizes brand equity estimation as an important marketing activity, the quantification of the returns on marketing activities in financial terms continues to be a major challenges for marketing and brand managers (Mizik \& Jacobson, 2008) as the instrumentation that firms use to measure the actual return on investment in marketing is still incipient (Rust et al., 2004). 
This study examines Korean firm's brand equity, based on Simon and Sullivan's model which is tailored to approximate the characteristics of Korean industrial structure and to reflect the time period of global financial crisis (2005-2010). We chose this time period to determine whether or not marketing investments of Korean firms had led to positive growth and profit when the market showed considerable disturbance. Understanding of the relationship between firm performance and branding investment enables validation of marketing accountability and securing marketing expenditure in firm's overall budget.

\section{Conceptual Background}

\section{Brand Equity Measurement}

Various forms of estimation approaches for capturing brand equity prevail and research in brand valuation has not yet come up with a single, uniformly accepted theoretical basis (Madden et al., 2006; Raggio \& Leone, 2007; Shankar et al., 2008; Buil et al., 2013; Oliveira et al., 2015). Researchers have not reached a consensus about which measures provide the best estimates of brand equity, in part because different perspectives exist to define and measure this concept, such as financial or consumer perspectives (Buil et al., 2013; Keller 1993). Studies on brand equity measurement can be classified based on the level at which the brand equity outcome is measured; the consumer-based perspective (Keller, 1993) proposes individual consumer-level measures, while the productmarket perspective (Leuthesser 1988; Keller \& Lehmann 2003 \& 2006) expounds market-level measures (Voleti et $a l ., 2012$ ). The consumer-based perspective illustrates the effects of marketing activities on the consumers' response to brand (i.e. brand awareness, brand preference, increase in sales) which is translated into brand equity. This approach is conceptualized as 'Consumer-Based Brand Equity (CBBE)' by Aaker (1991) and Keller (1993) and receives significant attention from the academic and business community (Kim et al.,2003; Kim et al., 2014; Kim \& Brandon,2010; Zhang et al., 2010; Cifci et al., 2016). This approach is widely used in assessing customer equity, differentiating brands and brand performance.

The CBBE focuses on consumer perception constructs such as attitude, awareness and preference for a particular brand, and translate these perceptual measures into brand equity measures such as brand affect (Bousch et al., 1987) and brand-specific associations (Bhat \& Reddy, 2001; Muhlbacher et al., 2016). These studies employed survey or experimental data which are mostly collected at individual level, and are limited in its implications as they are subject to experimental design of the selected marketing mix and the data quality. Consumer-based approach falls short in linking how consumers perceive/value brand with firm-level performance and do not offer a monetary estimation of brand equity (Oliveira $e t$ al., 2015) as survey method primarily collect data on consumers' preference or intention for brand purchase/choice. A major problem with the existing CBBE models is the lack of theoretical foundation for the drivers of brand equity (Buil et al., 2013). Nam et al. (2011) state that applications of the CBBE measures are limited as brand equity measure, and CBBE showed poor validity in assessing service brands (Boo et al., 2009). Cifci et al., (2016) compared the validity of the two prominent CBBE models which were introduced by Yoo \& Donthu (2011) and Nam et al. (2011) and draw the relationship between brand awareness, brand satisfaction and brand loyalty, emphasizing the importance of brand knowledge in applying the CBBE model to service brands. In addition, most extant literature focuses on brand equity as a construct, thus failing to recognize a dynamic and sequential process of brand relationship between consumer and brand. Chatzipanagiotou et al. (2016) proposed a framework with three blocks: brand building, brand understanding and brand relationships to capture the creation process of brand equity.

On the other hand, the product-market perspective elicits brand equity estimates from more accessible marketlevel outcome data which are routinely collected by the firms or syndicated data providers. This so-called 'Financial-Based Brand Equity' (FBBE) approach allows assessment of changes in the overall brand equity of a firm in the market; yet do not consider consumers' perception (Oliveira et al., 2015). Several studies use firm-level financial data such as acquisition prices (Mahajan, Rao \& Srivastava, 1994) and residual market values (Simon \& Sullivan, 1993; Ailawaldi et al., 2003; Yoo \& Donthu 2001; Srinivasan et al., 2005; Damodaran 2006; Tong \& Hawley 2009; Ferjani et al., 2009) to generate BE estimates (Voleti et al., 2012).

Simon and Sullivan (1993) states advantages of using financial market data for brand equity valuation; first, this approach allows comparison over time and across companies by using objective market-based measures; second, the effect of market size and growth or any other factors affecting future profitability can be implicitly incorporated in the assessment; third, both the revenueenhancing and the cost-reducing capabilities of brand equity are considered in the valuation. The financial market data approach, however has some caveats; it does not explicitly generate the value of individual brands. Firm's financial market data may include multi-brand information and by measuring firm level BE estimates, it is difficult to separate the specific effects of controllable marketing mix on a particular brand. Furthermore, noise effect can possibly bias the brand equity effects on the overall value of a firm when using macro-level assessment.

Nonetheless, it is worthwhile to study the brand equity at macro-level as it may provide valuable guidelines for future decision-making such as investment in brand management or innovative technology. By estimating brand equity at the firm level, firms can determine the effectiveness of a their marketing strategies relative to competitors and have strategic perspective on long term return on branding investments. There are some studies which used brand level market data such as sales, profits, price or syndicated individual level scanner choice data. Studies by Aaker 1991, 1996; Sethuraman 2003 used measures such as the additional willingness to pay for a branded product compared to an unbranded one; Chaudhari and Holbrook (2001) used market share and relative prices 
data; Kamakura and Russell (1993) used segment-wise brand preference data, Ailawadi, Lehmann and Neslin (2003) used revenue premiums; and Dubin (1998) \& Goldfarb, Lu and Moorthy (2007) used profit differential data to estimate BE. These studies could separate specific brand level $\mathrm{BE}$, however, they are still subject to the confounding brand selection and marketing mix.

\section{Research Framework}

In this paper, we follow Simon and Sullivan's approach (1993) which is one of the FBBE. This approach enables assessment of marketing productivity and brand equity, which are drawn from firm financial performance metrics based on firms' accounting and financial data (Lee, 2012). They argue that the brand equity is the total value of accumulated value or worth of a brand which is a part of the intangible assets that the brand contributes to its corporate parent financially. Thus, a firm's brand equity can be estimated based on financial market estimates of brand-related profits. Simon and Sullivan define the financial market value of a firm as the aggregate earning power of its assets. This entails tangible and intangible assets and brand equity is a part of "intangible" asset. They estimated the current market value of the firms initially, which provides an unbiased estimate of the future cash flows that are attributable to firm's assets, then classified tangible and intangible assets of the firm's value in order to extract brand equity out of the intangible assets.

\section{R\&D Equity Measurement}

In this study, we propose that brand equity is one of the three selected intangible assets: 1) brand equity, 2) $\mathrm{R} \& \mathrm{D}$ equity and 3 ) the value of other firm-specific factors not associated with brand equity or R\&D equity. We included $R \& D$ equity as one of the determinants of intangible assets in order to accommodate the distinctive characteristics of Korean firms and industrial structures. Large proportion of Korean industries composes of manufacturing-intensive sectors, which continuously invest on $\mathrm{R} \& \mathrm{D}$ to enhance innovative technology and to maximize efficiency in their operational processes. Investments on $\mathrm{R} \& \mathrm{D}$ may bring innovative technology which may contribute to firm's productivity, sales, profitability and competitive position in the market. Thus, $\mathrm{R} \& \mathrm{D}$ equity may represent significant parts of the intangible assets, particularly in Corporate Korea which attribute to firm profit and financial performance. The estimates of brand equity elicited in this study are likely to be subject to the selected determinants representing the three components of intangible assets in our model.

We also included a dummy variable to account for the value of other firm-specific factors not associated with neither of brand equity or $R \& D$ equity such as unique corporate culture or superior leadership of CEO. In addition, we incorporated a variable accounting for the change in firm's stock prices, reflecting the volatility in the stock price of each firm. It is included to minimize the effect of the abnormality in the financial market data since the wide swing in the financial market during global financial crisis may cause over/under estimation of the model. This is an important modification in the model as it reduces any biases which may arise due to the estimation of financial market data for global financial crisis period.

\section{Model Development: Brand Equity Model of Firms Listed in KRX} follow:

The total value of the firm's asset can be specified as

$$
V_{F}=V_{T}+V_{I}
$$

Where $V_{T}$ is the value of the firm's tangible assets, which comprises of liquid asset ( $V_{\text {current }}$ ), invested assets $\left(V_{\text {Invested }}\right)$, tangible fixed assets $\left(V_{T \text { fuxed }}\right)$ and gain/loss from valuation $\left(V_{V G L}\right)$;

$V_{I}$ is the value of the firm's intangible assets, which consists of intangible fixed assets $\left(V_{\text {If ixed }}\right)$, deferred assets $\left(V_{\text {deferned }}\right)$ and other intangible assets $\left(V_{o}\right) .\left(V_{V G L}\right)$;

$$
\begin{aligned}
& V_{T}=V_{\text {current }}+V_{\text {Invested }}+V_{T \text { fixed }}+V_{V G L} \\
& V_{I}=V_{\text {Ifixed }}+V_{\text {defierred }}+V_{o} \\
& V_{o}=V_{\text {MVS }}-V_{E}-V_{V G L}
\end{aligned}
$$

$V_{o}$ is the difference between the total market value of shares $\left(V_{M V S}\right)$ and the book value of equity $\left(V_{E}\right)$ and the gain/loss from valuation $\left(V_{V G L}\right)$.

$$
V_{I}=V_{b}+V_{r d}+V_{o}
$$

Where $V_{I}$ is the value of intangible assets which comprises of the value of brand equity $\left(V_{b}\right)$; the value of $\mathrm{R} \& \mathrm{D}$ equity $\left(V_{r d}\right)$ and the value of other intangible assets $\left(V_{o}\right)$.

$$
\begin{aligned}
& V_{b}=\mathrm{f}(\mathrm{M}, \mathrm{MS}, \mathrm{A}, \text { Ord }) \\
& V_{r d}=\mathrm{f}(\mathrm{RD}, \mathrm{RDS}, \mathrm{P}, \mathrm{PS})
\end{aligned}
$$

$V_{b}$ is made of four components such as marketing expenses (M); the share of marketing expenses of a brand relative to its competitors' marketing expenses (MS), which can be considered as proxies for information expenditures and positioning advantages (Simon \& Sullivan, 1993); the age of the firm (A); and the order of market entry (Ord). $V_{r d}$ comprises of four factors: the value of R\&D expenditure by the firm (RD); the share of R\&D expenditure of the firm relative to its competitors' expenditure on R\&D (RDS); the number of patents held by the firm $(\mathrm{P})$; and the share of patents ownership of the firm relative to its competitors' share of patents (PS).

\section{A Firm's Market Share Equations for Brand Equity and $R \& D$ Equity Valuation}

Among these determinants, some of them affect a firm's competitive position in the market and tend to contribute to the firm's market share in the industry. In particular, MS, Ord, RDS and PS are directly related to the 
Renee B. Kim, Dong Hyun Yoon. Marketing Accountability of Korea Corporate: The Relationship between Branding ...

firm's market share in the industry. Therefore, we used a two-stage estimation technique to reflect this market circumstances. In the first stage of our estimation, we used the factors- MS, Ord, RDS and PS relative to its competitors' share (i.e. $S_{b}$ and $S_{r d}$ ) as following to derive Firm's market share equations:

$$
\begin{aligned}
& S_{F}=S_{b}+S_{r d}+S_{o} \\
& S_{b}=\mathrm{f}(\mathrm{MS}, \text { Ord }) \\
& S_{r d}=\mathrm{f}(\mathrm{RDS}, \text { PS })
\end{aligned}
$$

With above procedure, the value of the brand equity and the value of R\&D equity can be written as following:

$$
\begin{aligned}
& V_{b}=\mathrm{f}\left(\mathrm{M}, \mathrm{A}, S_{b}\right) \\
& V_{r d}=\mathrm{f}\left(\mathrm{RD}, \mathrm{P}, S_{r d}\right)
\end{aligned}
$$

The firm's market share can be regressed on the following explanatory factors:

$$
\begin{aligned}
& S_{T}=b_{0}+b_{1} * \mathrm{MS}+b_{2} * \text { Ord }+b_{3} * \mathrm{RDS}+b_{4} * \mathrm{PS}+\epsilon \\
& E\left(S_{b}\right)=\widehat{b}_{1} * \mathrm{MS}+\hat{b}_{2} * \text { Ord } \\
& E\left(S_{r d}\right)=\widehat{b}_{3} * \mathrm{RDS}+\widehat{b}_{4} * \mathrm{PS}+\widehat{\epsilon} \\
& S_{o}=S_{T}-E\left(S_{b)}-E\left(S_{r d}\right)\right.
\end{aligned}
$$

\section{A Firm's Intangible Asset Equation for Brand Equity and $R \& D$ Equity Valuation}

From equations (14), (15), and (16), the market share estimates of $E\left(S_{b}\right), E\left(S_{r d}\right)$, and $S_{o}$ are derived which are combined with other selected determinants to arrive at a reduced form structural equation for estimation of the determinants of $V_{b}$ and $V_{r d}$ in equation (17)-(20).

$$
\begin{aligned}
& V_{I}=\beta_{0}+V_{b}+V_{r d}+V_{o} \\
& V_{b}=\beta_{1} * \mathrm{M}+\beta_{2} * \mathrm{~A}+\beta_{3} * S_{b} \\
& V_{r d}=\beta_{4} * \mathrm{RD}+\beta_{5} * \mathrm{P}+\beta_{6} * S_{r d} \\
& V_{o}=\sum_{j=1}^{17} \beta_{7 j} * D_{j}+\beta_{8} * S_{o}+\beta_{9} * \mathrm{SP}
\end{aligned}
$$

\section{Results}

\section{Characteristic of the Sample}

In this study, a sample 514 firms on the Korean Stock Exchange listing (i.e. KOSPI and KOSDAQ) from 17 different industries are selected in order to evaluate brand equity and R\&D equity. For this study, we have collected data of market value of the shares of the firms, firms' financial information, firms' history, number of patents from the services of Dataguide, and Patent Office(www.kipris). The firms in the sample are officially listed before 2005, of which the intangible asset values are above zero. Firms in the sample were selected for the sample: (1) 1,635 firms were publicly listed on the KOSPI and KOSDAQ, excluding the firms in the financial service sector; (2) the firms were from twelve different manufacturing sectors and five service sectors; (3) the firms were established for more than 8 years.

\section{Estimates of the Market Share, Brand Equity \& R\&D Equity}

In order to take into account of the effects of brand strength and R\&D focus on firm's market share, the firm's market share has been apportioned into brand-related, $\mathrm{R} \& \mathrm{D}$ related and others components and estimated. The market share equation (13) was estimated as following ${ }^{1}$ :

$$
\begin{aligned}
& \hat{S}_{T=-} \\
& 0.011+0.153 * \mathrm{MS}+0.068 * \mathrm{MS}_{t-2}+0.006 * \operatorname{Ord}_{\log }+0.288 * \mathrm{R} \\
& \mathrm{DS}+0.161 * \mathrm{PS}
\end{aligned}
$$

Estimates of equation (21) shows that brand and R\&D factors contribute to the market share of the firm, and the share of R\&D investments by the firm and the share of patents ownership were found to have greater impacts on the firm's market share compared to the share of marketing expenses. The share of marketing expense by the firm appears to have lagged effects on the firm's position in the market. Equations (14) and (15) were regressed to derive the estimates of the market share attributable to brand equity and R\&D equity:

$$
\begin{aligned}
& \hat{S}_{b}=0.153 * \mathrm{MS}+0.068 * M S_{t-2}+0.006 * \text { Ord } \\
& \hat{S}_{r d}=0.288 * \mathrm{RDS}+0.161 * \mathrm{PS}
\end{aligned}
$$

In order to compare measured brand equity and R\&D equity across companies of different sizes, $\widehat{V}_{b}$ and $\widehat{V}_{r d}$ were estimated as a percentage of tangible asset value $\left(V_{T}\right)$ (i.e. $V_{I} / V_{T}=$ (Tobin's Q-1) and the value of intangible assets $\left(V_{I}\right)$ and other independent variables in the equation (23) were scaled (Simon \& Sullivan, 1993) ${ }^{2}$.

$$
\begin{gathered}
\widehat{V}_{I}=3.249 * \mathrm{M}+0.201 * \mathrm{~A}+6.596 * S_{b}+8.072 * R D_{t^{-}} \\
2.200 * R D_{t-1}+1.335 * R D_{t-2} \\
\quad+0.093 * P_{\log }-5.557 * S_{r d}+\sum_{j=1}^{17} \beta_{11 j} * D_{j^{-}} \\
0.968 * S_{o}+0.169 * \mathrm{SP} \\
\widehat{V}_{b}=3.249 * M_{t}+0.201 * A_{\log }+6.596 * S_{b} \\
\widehat{V}_{r d}=8.072 * R D_{t^{-}} \\
2.200 * R D_{t-1}+1.335 * R D_{t-2}+0.093 * P_{\log }-5.557 * S_{r d}(26)
\end{gathered}
$$

Estimated coefficients in the equations (25) and (26) were drawn from the estimation of equation (24), and these were interpreted in this study as rates of return on "investments" in brand assets and R\&D assets, which followed the study of Simon \& Sullivan. For example, there is a thirty two percent return on marketing investment in the current period, and an eighty percent return on R\&D investments in the current period. Particularly, the R\&D investments from previous term $(\mathrm{t}-2)$ appear to have lasting effects on the firm's R\&D equity. In the final estimation of equation (24), a dummy variable was added to the regression to account for the different characteristics of

\footnotetext{
$1 \mathrm{R}^{2}=0.770$ and the t-statistics are in parentheses.

2 Scaling improves the issues of heteroscedasticity which arise due to the different numerical values of each determinant.

$3 \mathrm{R}^{2}=0.301$.
} 
each industry unobserved in this analysis. The estimated coefficient on the dummy variable was relatively large and statistically significant.

Table 1 reports the estimates of brand equity $\left(V_{b}\right)$, R\&D equity $\left(V_{r d}\right)$ and intangible asset $\left(V_{I}\right)$ values of South Korean Firms by industry in 2010. The proportion of intangible asset value ascribed to brand equity $\left(V_{b} / V_{I}\right)$ is also reported in this table. Overall, results show that industry groups vary in terms of the proportion of brand equity to intangible asset value. The estimated brand equity ranged from 36.7 percent to 63.1 percent, and the average of brand equity estimates for the sample was 43.5 percent.

On the other hand, the estimated R\&D equity ranged from -22.2 percent to 48.1 percent, with an average estimate of 29 percent for 514 firms. It appears that there is more variance in the $R \& D$ equity value among the industry relative to brand equity value. The industries that sell consumer products appear to have high estimates of brand equity and low estimates of R\&D equity. On the other hand, IT sectors, electronics manufacturing sector, heavy machinery were found to have high value of $R \& D$ equity estimates and low value of brand equity estimates.

The ratios of BE to intangible asset value $\left(V_{b} / V_{I}\right)$ in Table 1 showed that construction industry (2.24), Food \& Beverage industry (1.42) and Broadcasting industry (1.66) had the highest value, indicating that high proportion of intangible asset value attribute to brand-related activities. In South Korea, the brand names of the construction companies are heavily branded and the high proportion of South Korean residence in apartments led to high level of brand awareness of the companies in the construction industry. Also, there are three major nation-wide broadcasting companies in the broadcasting industry in South Korea, which are recognized by most of South Korean citizens. Thus, highly visible brand names of these companies are likely to reflect in the high value of brand equity. Products in the food $\&$ beverage sector are also heavily branded and have highly consumer-oriented, and this characteristics was reflected in the estimate of the $\mathrm{BE} /$ intangible asset value ratio $\left(V_{b} / V_{I}\right)$ (Table 1$)$.

\section{Estimates of Brand Equity and R\&D Equity for the Pharmaceutical Companies in South Korea}

Table 2 reports the estimates of brand equity and R\&D equity and intangible asset value of the thirty two firms in the pharmaceutical industry in South Korea. It is worthwhile to have a closer look at this particular industry since the pharmaceutical industry was found to have the highest value of intangible assets among 17 selected industries in the sample ${ }^{4}$ (Table 1). This industry is also found to have the fourth highest value of brand equity among 17 industries $^{5}$. It shows that there is a significant variance among the thirty two pharmaceutical firms in South Korea regarding the estimates of brand equity and

\footnotetext{
${ }^{4}$ The value of intangible asset for pharmaceutical industry was estimated to be 124.7 percent, while the overall average value of intangible assets for selected 17 industries was 72.8 percent.

5 The estimated value of brand equity for pharmaceutical industry was 52.8 percent.
}

R\&D equity. It is interesting to find out that the firms with high brand equity did not necessarily have high R\&D equity. The top three firms with high brand equity estimates (i.e. Dong-A, Daewon and Chongkundang) were found to have relatively low R\&D equity. Their highly visible brand names through heavy media advertisement and over-the-counter products (some of their products are allowed to be sold in the regular retail market) may lead to high value of brand equity estimates.

On the other hand, the top three firms with high R\&D equity estimates (i.e. Medi-post, LG Life Sciences and Han-ol Bio Pharma) are the ones with innovative technology which are expected to introduce new innovative products into the market, which may lead to over valuation of the stock price in the market. Thus, pharmaceutical firms appear to have wide range of brand equity and R\&D equity subject to strategic focus of each specific firm. Firms with high emphasis on branding led to high brand equity value with heavy marketing investments, while firms with high emphasis on innovation and technology show high value of $R \& D$ equity with heavy R\&D investments.

\section{Conclusions}

Findings Corporate Korea has considerable marketing accountability during the economic downturn (i.e. global financial crisis) with relatively high brand equity values. The value of the brand equity of selected 514 firms in South Korea for the period of 2005-2010 was estimated to range between 36.7 percent and 63.1 percent with an increasing rate, and this implies that South Korean firms' marketing investments led to increased brand equity and financial performance as the change in brand value can be considered as an outcome of their marketing activities. Transportation \& Warehouse sector showed the highest brand equity value with $63.1 \%$, while IT hardware and non-electric machinery sectors showed the lowest brand equity value. Transportation \& Warehouse sector include two exclusive South Korea airline carriers and other major transportation firms which run active promotional activities, investing heavily in marketing and branding. IT hardware sector consist of firms competing on their efficiency, and innovative technology, thus more likely to invest in $R \& D$, showing high value of $R \& D$ equity.

Corporate Korea showed R\&D equity, with an average of 29 percent, which was relatively lowered than brand equity (43.5 percent), and showed more variance among the 17 industries. Thus, the return on R\&D investments for Corporate Korea appears to be less prolific compared to that of the investments on branding and marketing.

Among the selected 17 industries of Corporate Korea, transportation \& warehouse, publishing, broadcasting \& communication and Transportation industries are the ones with highest estimates of brand equity in South Korea. On the other hands the pharmaceutical industry, IT Hardware and Software industries are found to have the highest estimates of R\&D equity. This suggests that consumeroriented industries exhibit high value of brand equity, while commodity based industries show high value of R\&D equity. Furthermore, companies with high recognition in South Korea exhibited high value of brand 
Renee B. Kim, Dong Hyun Yoon. Marketing Accountability of Korea Corporate: The Relationship between Branding ...

equity, and companies in innovative technology-intensive sectors exhibited high estimates of R\&D equity.

Broadcasting industry and pharmaceutical industry are the ones with high entry barrier as a firm need to have advanced technical know-hows and innovative systems to compete in these fields. Both of these two industries have high estimates of brand equity, while the pharmaceutical industry has high R\&D equity, and the broadcasting industry has low R\&D equity. Presumably the early movers to an industry with high entry barrier may not need to invest extensively on marketing since the pre-existing firms may be considered to secure stable market shares in these industries with high R\&D equity, while new comers may have limited access to such industry. The results show contradictory to this notion. Broadcasting industry was found to have relatively low R\&D equity due to its heavy reliance on outsourcing for its telecommunication technology and system, while pharmaceutical industry has high value of $\mathrm{R} \& \mathrm{D}$ equity as it needs to produce its products with innovation and high technology independently. On the other hand, both of these industries have high value of brand equity. Broadcasting industry in South Korea has oligopolistic structure in which firms compete on marketing their brand images with heavy marketing investments, leading to high estimates of brand equity. The firms in pharmaceutical industry in South Korea invest heavily on promoting their branded products, which affect the brand equity estimates.

Our study demonstrates that Corporate Korea demonstrated marketing productivity during the Global Financial Crisis period, showing 43.5 percent of brand equity value on average. The results validate the relationship between firm's marketing investments and their financial performance. This suggests that Corporate Korea may need to further expand its marketing investments to enhance the brand equity value which may help its competitiveness and positioning in the global market place, including non-Asian markets. Nonetheless, our estimates of brand equity and R\&D equity are limited in approximating equity values of specific brand or brand categories at the firm-level due to limited access to confidential firm-level data. Thus, application of financial data to estimate equity values of intangible assets is ultimately subject to the extent of data accessibility at firmlevel, and more detailed data at firm-level would enable comprehensive analysis and marketing implications for managers.

\section{Acknowledgement}

This work was supported by the Research Fund of Hanyang University (HY 2018).

Brand Equity and R\&D Equity by Industry, 2010 Average

\begin{tabular}{|c|c|c|c|c|}
\hline Industry & $V_{I}$ & $V_{b}$ & $V_{\text {rd }}$ & $V_{b} / V_{I}$ \\
\hline Food \& Beverage & 33.6 & 47.6 & 5.8 & 1.42 \\
\hline Textile \& Apparel & 69.8 & 41.3 & 15.5 & 0.59 \\
\hline Paper, Timber \& Publishing & 78.2 & 55.7 & 3.8 & 0.71 \\
\hline Chemicals & 61.4 & 44.6 & 21.2 & 0.73 \\
\hline Pharmacy & 124.7 & 52.8 & 48.1 & 0.42 \\
\hline Ore \& Metal & 65.0 & 44.2 & 5.8 & 0.68 \\
\hline Non Electric Machinery & 66.0 & 38.8 & 27.7 & 0.59 \\
\hline Electric Machinery & 52.0 & 44.6 & 28.8 & 0.86 \\
\hline IT Hardware & 64.3 & 36.7 & 45.4 & 0.57 \\
\hline Measurement \& Medical Equip. & 58.3 & 42.9 & 37.1 & 0.74 \\
\hline Transportation Equipment & 56.1 & 46.3 & 32.2 & 0.83 \\
\hline Distribution \& Power Generation & 91.3 & 41.5 & 19.0 & 0.45 \\
\hline Construction & 20.2 & 45.3 & 14.0 & 2.24 \\
\hline Transportation \& Warehouse & 46.8 & 63.1 & -22.2 & 1.35 \\
\hline Broadcasting \& Communication & 32.5 & 54.0 & 11.4 & 1.66 \\
\hline IT Software \& SVC & 94.5 & 40.2 & 46.9 & 0.43 \\
\hline Holding firm\& Service & 112.7 & 45.6 & 25.1 & 0.40 \\
\hline Average & 72.8 & 43.5 & 29.0 & 0.60 \\
\hline
\end{tabular}


Estimated Brand Equity for Pharmaceutical Firms in South Korea, 2010 Average

\begin{tabular}{|c|c|c|c|c|c|c|c|}
\hline Firm & $V_{I}$ & $V_{b}$ & $V_{\text {rd }}$ & Firm & $V_{I}$ & $V_{b}$ & $V_{\text {rd }}$ \\
\hline Komi pharm & 991.5 & 32.5 & 39.3 & Bukwang Pharm & 48.5 & 52.4 & 43.4 \\
\hline Medi-Post & 590.4 & 36.7 & 170.7 & Yuhan Yangheng & 44.5 & 68.2 & 24.3 \\
\hline JW-shinyak & 408.6 & 70.3 & 59.6 & Yungjin Pharm & 43.8 & 58.5 & 30.5 \\
\hline Celltrion & 320.2 & 35.6 & 54.7 & Daewoong Pharm & 43.3 & 47.0 & 0.9 \\
\hline $\begin{array}{l}\text { Hanol Bio } \\
\text { Phama }\end{array}$ & 227.6 & 53.7 & 117.8 & Cell Biothech & 42.6 & 34.5 & 31.8 \\
\hline Cavac & 179.7 & 33.8 & 35.8 & $\begin{array}{l}\text { Daehan New } \\
\text { Pharm }\end{array}$ & 35.4 & 43.7 & 14.6 \\
\hline $\begin{array}{l}\text { LG Life } \\
\text { Sciences }\end{array}$ & 156.5 & 33.7 & 124.1 & Wooridul Pharm & 33.7 & 62.4 & 9.8 \\
\hline Choa Pharm & 128.2 & 46.4 & 26.1 & Kyungnam Pharm & 26.1 & 39.9 & 6.6 \\
\hline Green Cross & 114.6 & 49.1 & 56.5 & Boryung Pharm & 13.6 & 66.3 & 53.6 \\
\hline K-stemcell & 112.0 & 55.9 & 28.8 & Daewon Pharm & 9.0 & 92.8 & 42.3 \\
\hline $\begin{array}{l}\text { Korea Bone } \\
\text { Bank }\end{array}$ & 82.5 & 39.9 & 49.2 & Samjin Pharm & 5.1 & 78.5 & 37.9 \\
\hline Sky New Pharm & 80.5 & 37.6 & 16.4 & United Pharm & 4.1 & 54.5 & 92.3 \\
\hline Il Yang Pharm & 67.1 & 55.3 & 23.4 & Chongkundang & 3.4 & 80.5 & 61.1 \\
\hline Binex & 64.6 & 42.0 & 19.2 & Jeil Pharm & 2.0 & 63.5 & 38.8 \\
\hline Bioneer & 56.7 & 37.4 & 116.4 & JW Pharm & 0.4 & 58.7 & 42.4 \\
\hline Dong-A Pharm & 55.7 & 94.9 & 38.8 & Estech Pharma & 0.1 & 32.6 & 30.6 \\
\hline
\end{tabular}

\section{References}

Aaker, D. A. (1991). Managing Brand Equity. Capitalizing on the Value of a Brand Name. New York: Free Press.

Aaker, D. A., \& Jacobson, R. (1994). The Financial Information Content of Perceived Quality. Journal of Marketing Research, 31(3), 191-201. https://doi.org/10.2307/3152193

Ailawadi, K., Lehmann, D., \& Neslin, S. (2003), Revenue Premium as an Outcome Measure of Brand Equity. Journal of Marketing Research, 67, 1-17. https://doi.org/10.1509/jmkg.67.4.1.18688

Bhat, S., \& Reddy, S. (2001), The Impact of Parent Brand Attribute Associations and Affect on Brand Extension Evaluation. Journal of Business Research, 53(3), 111-122. https://doi.org/10.1016/S0148-2963(99)00115-0

Boo, S., Busser, J., \& Baloglu, S. (2009). A model of customer-based brand equity and its application to multiple destinations. Tourism Management, 30(2), 219-231. https://doi.org/10.1016/j.tourman.2008.06.003

Bousch, D. Shipp, S., Loken, B., Genturck, E., Crockett, S., Kennedy, E., Minshall, B., Misurell, D., Rochford, L. and J. Strobehl (1987), Affect Generalization to Similar and Dissimilar Brand Extensions. Psychology and Marketing, 4, 225-237. https://doi.org/10.1002/mar.4220040306

Buil, I., de Chernatony, L., \& Martinez, E. (2013). Examining the role of advertising and sales promotions in brand equity creation. Journal of Business Research, 66, 115-122. https://doi.org/10.1016/j.jbusres.2011.07.030

Chaudhari, A., \& Holbrook, M. (2001), The Chain of Effects from Brand Trust and Brand Affect to Brand Performance: The Role of Brand Loyalty. Journal of Marketing, 6), 81-93.

Kamakura, W., \& Russell, G. (1993), "Measuring Brand Value with Scanner Data". International Journal for Research in Marketing, 10(1), 9-22. https://doi.org/10.1016/0167-8116(93)90030-3

Chattopadhyay, T., Shivani, S., \& Krishna, M. (2008). Approaches to Measurement of Brand Equity. Business \& Economics Conference Program, ISBN: 978-0-9742114-7-3, June 22-24, Oxford, UK.

Chatzipanagiotou, K., Veloutsou, C., \& Christodoulides, G. (2016), Decoding the complexity of the consumer-based brand equity process. Journal of Business Research, 69, 5479-5486. https://doi.org/10.1016/j.jbusres.2016.04.159

Christodoulides, G., \& de Chernatory, L. (2015). Consumer-based brand equity conceptualization and measurement. International Journal of Market Resaerch, 52(1), 43-66.

Damodaran, A. (2006). Dealing with intangibles: Valuing brand names, flexibility and patents. Working paper. New York: New York University. 
Renee B. Kim, Dong Hyun Yoon. Marketing Accountability of Korea Corporate: The Relationship between Branding ...

Dubin, J. (1998), The Demand for Branded and Unbranded Products: An Econometric Method for Valuing Intangible Assets, Chapter 4 in Studies in Consumer Demand: Econometric Methods Applied to Market Data, Norwell, MA. Kluwer Academic Publishers, 77-127.

Ferjani, M., Jedidi, K., \& Jagpal, S. (2009). Consumer-and firm-level brand valuation. Journal of Marketing Research, XLVI, 846-862. https://doi.org/10.1509/jmkr.46.6.846

Gray, B. J. (2006). Benchmarking Services Branding Practices. Journal of Marketing Management, 22(7-8), 717-758. https://doi.org/10.1362/026725706778612095

Goldfarb, A., Lu, Q., \& Moorthy, S. (2007) Measuring Brand Value in an Equilibrium Framework, SSRN Working Paper, University of Toronto.

Heines, Richard A., Robert T. Leach, Leanne C. McGrath (2012). Assessing the Importance of Brand Equity in Health Services Marketing Through the Impact of Acquired Goodwill on Stockholder Returns. Journal of Economics and Behavioral Studies, Vol.4, No.6, pp. 364-370.

Keller, K. (1993), Conceptualizing, Measuring and Managing Customer-Based Brand Equity. Journal of Marketing, 57(1), 1-22. https://doi.org/10.2307/1252054

Keller, K., \& Lehmann, D. (2003). The Brand Value Chain: Optimizing Strategic and Financial Brand Performance, Marketing Management, 26-31.

Keller, K., \& D. Lehmann (2006), Brands and Branding: Research Findings and Future Priorities. Marketing Science, 25(6), 740-759. https://doi.org/10.1287/mksc.1050.0153

Kim, H., Kim, W. G., \& An, J. A. (2003). The effect of consumer-based brand equity on Firms' Financial performance. Journal of Consumer Marketing, 20(4), 335-351. https://doi.org/10.1108/07363760310483694

Kim, E.Y., \& Brandon, L. (2010). Modeling brand equity for lifestyle brand extensions: A strategic approach into Generation Y vs. Baby Boomer. Journal of Global Academy of Marketing Science, 20(1), 35-48. https://doi.org/10.1080/12297119.2010.9707342

Kim, K., Ko, E., Lee, M., Mattila, P., \& Kim, K. H. (2014). Fashion collaboration effects on Consumer response and customer equity in global luxury and SPA brand marketing. Journal of Global Scholars of Marketing Science, 24(3), 350-364. https://doi.org/10.1080/21639159.2014.913376

Kim, J. H. (2017). In an era of firm's brand dominate country brand, Vol.5, Daily Chosun Newsroom, 2017.

Lee, Hyunjung (2012). Brand Valuation Model: A Shareholder Value Approach. A dissertation at Kent State University.

Leuthesser, L. (1988), Defining, Measuring and Managing Brand Equity, Working Paper 88-104, Marketing Science Institute, Cambridge, MA.

Madden, T. J., Fehle, F., \& Fournier, S. (2006). Brands matter: An empirical demonstration of the creation of shareholder value through brands. Journal of the Academy of Marketing Science, 34(2), $224-235$. https://doi.org/10.1177/0092070305283356

Mahajan, V., Rao, V. and R. Srivastava (1994), An Approach to Assess the Importance of Brand Equity in Acquisition Decisions, Journal of Product Innovation Management, 11(3), 221-235. https://doi.org/10.1111/15405885.1130221

Mizik, N., \& Jacobson, R. (2008). The financial value impact of perceptual brand attributes. Journal of Marketing Research, XLV, 15-32. https://doi.org/10.1509/jmkr.45.1.15

Muhlbacher, H., Raies, K., Grohs, R. \& Koll, O. (2016). Drivers of brand strength: Configural paths to strong cognitive brand equity. Journal of Business Research, 69, 2774-2780. https://doi.org/10.1016/j.jbusres.2015.11.013

Nam, J., Ekinci, Y., \& Whyatt, G. (2011). Brand equity, brand loyalty and consumer satisfaction. Annals of Tourism Research, 38(3), 1009-1030. https://doi.org/10.1016/j.annals.2011.01.015

Oliverira M, C. S. Silveira, Fernando, B. L. (2015). Brand Equity Estimation Model. Journal of Business Research, 68, 2560-2568. https://doi.org/10.1016/j.jbusres.2015.06.025

Raggio, R. D., \& Leone, R. P. (2007). The theoretical separation of brand equity and brand value: managerial implications for strategic planning. Journal of Brand Management, 14(5), 380-395. https://doi.org/10.1057/palgrave.bm.2550078

Shankar, V., Azar, P., \& Fuller, M. (2008). Bran*eqt: A model and simulator for estimating, tracking, and managing multicategory brand equity. Marketing Science, 27(4), 567-584. https://doi.org/10.1287/mksc.1070.0320 
Simon, C., \& M. Sullivan (1993), The Measurement and Determinants of Brand Equity: A Financial Approach, Marketing Science, 12, 28-52. https://doi.org/10.1287/mksc.12.1.28

Srinivasan, V. (2005). An approach to the Measurement, Analysis and Prediction of Brand equity and Its Sources, Management Science, Sep. 2005, p.1434. https://doi.org/10.1287/mnsc.1050.0405

Voleti Sudhir, Paul Nelson and Sanjog Misra (2012). Brand Equity as a Revenue Multiplier. Working Paper, the William E. Simon Graduate School of Business Administration, University of Rochester

Yoo, B., \& Donthu, N. (2001). Developing and validating a multidimensional consumer-based brand equity scale. Journal of Business Research, 52(1), 1-14. https://doi.org/10.1016/S0148-2963(99)00098-3

Zhang, H., Ko, E., \& Kim, K. H. (2010). The influences of customer equity drivers on customer equity and loyalty in the sports shoe industry: Comparing Korea and China. Journal of Global Fashion Marketing, 1(2), 110-118. https://doi.org/10.1080/20932685.2010.10593063

The article has been reviewed.

Received in August, 2014; accepted in June, 2018. 